\title{
Histopathological alterations caused by monogenean parasites the gills of tambaqui Colossoma macropomum (Serrasalmidae)
}

\section{Alterações histopatológicas causadas por parasitos monogeneas nas brânquias de tambaqui Colossoma macropomum (Serrasalmidae)}

\author{
Marcos Tavares-Dias ${ }^{1 *}$; Gabriel Valente Ferreira ${ }^{2}$; Marcela Nunes Videira ${ }^{3}$
}

\section{Highlights}

Low monogeneans infection led to low to moderate alterations in gill tissues.

Hyperplasia, fusion, congestion and shortening of lamellae occurred.

Monogeneans may harm production of fish due to gill damages and mortality.

\begin{abstract}
Monogeneans are ectoparasites of fish with a global distribution. In farmed fish, high infestations may result in morbidity and mortality. This study investigated the histopathological effects of three species of monogeneans Anacanthorus spathulatus, Notozothecium janauachensis and Mymarothecium boegeri on the gills of farmed Colossoma macropomum. Parasitological indices revealed a prevalence of $100 \%$, and a mean abundance of $81.3 \pm 11.8$. This infection caused displacement of the gill epithelium, focal hyperplasia of epithelial cells, lamellar fusion, congestion and shortening of the secondary lamellae of gills, in addition a complete fusion of the secondary lamellae. However, these tissue alterations were reversible and punctually located lesions, which may not compromise the normal functioning of gills. Lastly, this study showed the potential damages caused by parasite monogeneans to gills of infested fish, thus sanitary management is essential for the growth of fish farm of C. macropomum.
\end{abstract}

Key words: Fish. Gills. Parasites. Tambaqui. Tissues alterations.

\section{Resumo}

Monogeneas são ectoparasitas de peixes com distribuição global. Em peixes de viveiro, altas infestações podem resultar em morbidade e mortalidade. Este estudo investigou os efeitos histopatológicos dos monogeneas Anacanthorus spathulatus, Notozothecium janauachensis e Mymarothecium boegeri. Os índices parasitológicos revelaram uma prevalência de 100\% e uma abundância média de 81,3 $\pm 11,8$.

1 Researcher, Embrapa Amapá, Macapá, PhD, Macapá, AP, Brazil. E-mail: marcos.tavares@embrapa.br

2 Graduate of Natural Sciences Curse, State University of Amapá, UEAP, Macapá, AP, Brazil. E-mail: gabriel.valente48@ gmail.com

3 PhD, Prof., Universidade do Estado do Amapá (UEAP), Macapá, AP, Brazil. E-mail: videiravet@gmail.com

* Author for correspondence

Received: June 08, 2020 - Approved: Feb. 24, 2021 
Essa infecção causou deslocamento do epitélio branquial, hiperplasia focal das células epiteliais, fusão lamelar, congestão e encurtamento das lamelas secundárias das brânquias, além de uma fusão completa das lamelas secundárias. Porém, essas alterações teciduais são lesões reversíveis e pontuais, que podem não comprometer o funcionamento normal das brânquias. Esses resultados mostram potencial danos de monogeneas nas brânquias dos peixes infestados, assim o manejo sanitário é essencial para o crescimento da piscicultura de C. macropomum.

Palavras-chave: Peixe. Brânquias. Parasitos. Tambaqui. Alterações teciduais.

Aquaculture plays an important role in providing food, livelihood, and a source of income in many countries. Global aquaculture production has grown rapidly over the past six decades and food production sector must continue to grow to meet increasing demands for high quality protein. Hence, aquaculture systems are increasing in intensification. However, confining fish in aquaculture can lead to several stressors including over-crowding, oxygen deficiency, aggression and nutritional deficiency, which increase the risk of parasite infestations. Ectoparasite infections are common in fish farming around the world and thus, disease management is crucial for the expansion of aquaculture as outbreaks of ectoparasite infections often cause significant losses in fish aquaculture (Hoai, 2020).

Among these parasites, species of Monogenea Van Beneden, 1858 are Platyhelminthes that have a simple and direct lifecycle, presenting a high reproduction rate in farmed fish. Monogeneans attach mainly to the gills of the hosts and can transfer between hosts at any stage of their lifecycle without a specific transmission stage. These ectoparasites can cause pathogenicity (Aragort et al., 2002; Kaur \& Shrivastav, 2014; Pahor, Klosterhoff, Marchiori, \& Pereira, 2017; Grano-Maldonado, Rodríguez-Santiago, García-Vargas, Nieves-Soto, \& Soares, 2018; Hoai, 2020). The pathogenicity can vary among species and in depending on infection levels. Igeh \& Avenant-Oldewage (2020) reported that the damaging effects of these parasites are noticed when changes occur within the host, such as physiological (e.g, cell proliferation, immunosuppression, altered growth and detrimental behavioral responses) or mechanical damages (e.g., fusion of gill lamellae, epithelial desquamation, hypertrophy, tissue replacement of gills). Hence, these ectoparasites can affect the health of fish and are one of the major factors that contribute to mortality and epizooties in farmed fish (Kaur \& Shrivastav, 2014; Pahor et al., 2017; GranoMaldonado et al., 2018).

Monogeneans have a high specificity to their fish host species, because they appear to infect hosts when both have experienced a coevolution (Boeger \& Viana, 2006, Whittington \& Chisholm, 2008; Braga, Araújo, \& Boeger, 2014). The infections of monogeneans in the of gills of Colossoma macropomum Cuvier, 1818 (tambaqui) can be caused by Anacanthorus spathulatus Kritsky, Thatcher \& Kayton 1979; Notozothecium janauachensis Belmont-Jégu, Domingues \& Martins 2004; Mymarothecium boegeri Cohen \& Kohn, 2005 and/or Linguadactyloides brinkmanni Thatcher \& Kritsky, 1983 (Aragort et al., 2002; Nogueira, Santos, \& Tavares-Dias, 2019). Despite the C. macropomum being a widely farmed fish throughout Brazil and other Amazon countries, the histopathological effects of infestation by monogeneans remain unknown. Thus, this study aimed to investigate the histopathological effects of $A$. spathulatus, 
$N$. janauachensis and $M$. boegeri in the gills of farmed C. macropomum.

The gills of 58 C. macropomum fingerlings (10.5 $\pm 0.8 \mathrm{~cm}$ and $21.2 \pm 3.4 \mathrm{~g})$, being 10 fish non-infected (control) and 48 fish infected by monogeneans were used in this study. Gills of 30 fish specimens were collected and fixed in $5 \%$ formalin solution for quantification and identification of the monogeneans (Eiras, Takemoto, \& Pavanelli, 2006; Boeger \& Viana, 2006), and to determine their prevalence and mean abundance (Bush, Lafferty, Lotz, \& Shostak, 1997). In addition, the first gill arch of both sides of 18 fish infected by monogeneans and of 10 fish non-infected (control) were collected and fixed in formalin buffer (10\%) and subjected to histopathological analyses. Gill arches were placed in a 10\% ethylene-diamine-tetra-acetic acid (EDTA) solution, for 7 days, for decalcification, and were then neutralized with a saturated saline solution. Gill arches were then dehydrated in a gradual series of ethanol solutions $(70,80$, $90,100 \%)$ and xylol baths, and embedded in paraffin to obtain consecutive $5-\mu \mathrm{m}$ sections using a microtome (Thermo ScientificTM HM 340E, USA). Histological sections were prepared and stained with hematoxylin and eosin (HE). Images were taken using a common optical microscope (Leica DM 1000, USA) and the software Leica Application Suite 1.6.0 software. Histopathological analyses were performed in a semiquantitative manner using mean assessment values/MAV (Schwaiger et al., 1997) and the histopathological alteration index/HAl (Poleksić \& MitrovićTutundžić, 1994). Alterations were evaluated semiquantitatively by ranking the severity of tissue lesions. Ranking was: grade $1=$ no pathological alterations, grade $2=$ focal mild to moderate changes and grade $3=$ extended severe pathological alterations. This ranking was used to establish an overall assessment value of the histopathological lesions for each organ of each individual fish. The changes were classified in progressive phases of tissue damages: changes in stage I, which do not compromise the functionality of the gills; stage II, more severe and impair the functionality of the gills; and stage III, very severe and irreversible damage to the gills.

The prevalence and abundance of $A$. spathulatus, M. boegeri and $N$. janauachensis showed variations in the gills of $C$. macropomum (Table 1), and the prevalence was higher when compared to that reported by Aragort et al. (2002) for this host infected with $A$. spathulatus and L. brinkmanni. Studies have reported the potential damages caused by monogeneans in infected fish (Aragort et al., 2002; Campos, Moraes, \& Moraes, 2011; Pahor et al., 2017). Monogeneans proliferate rapidly in rearing systems and attack using its haptor that has abrasive activity (Pahor et al., 2017; Hoai, 2020), which can harm production of fish farming due to respiratory damages and mortality.

\section{Table 1}

Parasitological indices of monogeneans on the gills of farmed Colossoma macropomum

\begin{tabular}{ccc} 
Parasite species & Prevalence (\%) & Mean abundance \\
\hline Anacanthorus spathulatus & 100 & $149.3 \pm 14.6$ \\
Mymarothecium boegeri & 52.0 & $72.3 \pm 12.7$ \\
Notozothecium janauachensis & 47.0 & $22.4 \pm 8.3$
\end{tabular}


Gill filaments in most fish are long and narrow projections lateral to the gill arch that taper at their distal end. Each filament is supplied with blood from an afferent filamental artery that extends along the filament. The epithelium that covers the gill filaments and lamellae provides a distinct boundary between the external environment of the fish and extracellular fluids and plays a critical role in the physiological function of the gills. Thus, the gills of freshwater teleost fish, which are responsible for ion uptake, acid-base transport and exchanges of respiratory gases (Evans, Piermarini, \& Choe, 2005), can be harmed from damages to their structure as the caused by monogeneans.

In C. macropomum with a low infection of $A$. spathulatus, M. boegeri and $N$. janauachensis, the tissue changes of gills were predominantly of stage I lesions, i.e., displacement of the epithelium (89.0\%), focal hyperplasia of epithelial cells (77.7\%), lamellar fusion (55.5\%), congestion (33.3\%) and shortening of the secondary lamellae (22.2\%). Only $22.2 \%$ of the gills presented complete fusion of the secondary lamellae, being classified as stage II lesions (Figure 1). The histopathological alteration index (HAl) per individual ranged from 2 to 14 , and the mean value of the $\mathrm{HAl}$ was 4 , showing that the gills of the fish presented reversible and punctual lesions and that the functionality of this respiratory organ was not compromised. In contrast, infestation by monogeneans caused hyperplasia of the gill epithelium of wild Prochilodus lineatus Valenciennes, 1836, of which the parasites proliferated in the interlamellar epithelium and partial fulfillment of the spaces between the lamellae, causing fusion of the gill arches. Structural disorganization of gill lamellae and presence of mononuclear inflammatory cells and focal interstitial hemorrhage in the distal region of the gill lamellae have been also reported (Campos et al., 2011).

Monogeneans were present in some samples of C. macropomum gills, and a low mean abundance $(81.3 \pm 11.8)$ caused low to moderate alterations in gill tissue. On the other hand, low infection by L. brinkmanni in $C$. macropomum gills led to severe inflammation, rich in macrophages and lymphocytes, with metaplasia, loss of lamellas, epithelial cell atrophy, and tissue was observed to encapsulate the parasite (Aragort et al., 2002). Nevertheless, the presence of this monogenean species was not observed in the present study. A high infestation of Ligophorus uruguayense Siquier \& Ostrowski de Núñez, 2009 also caused severe damage in the gills of wild Mugil liza Valenciennes, 1836, such as low incidence of severe hyperplasia and necrosis of the respiratory epithelium of the hosts (Pahor et al., 2017). Moderate infestation of Gyrodactylus cichlidarum Paperna, 1968 caused a swelling of the apex of the primary and secondary lamellae with hyperplasia in the gills of Oreochromis niloticus Linnaeus 1756 , with the presence of a large number of undifferentiated proliferating cells, hypertrophy and interlamellar necrosis, which lead to mortality (Grano-Maldonado et al., 2018). In the gills of Pseudocrenilabrus philander Weber, 1897, attachment of Cichlidogyrus philander Douëllou, 1993 resulted in compression, rupturing of the interlamellar epithelium, change in the organization of epithelial cells in both primary and secondary lamella, displacement of the extracellular cartilaginous matrix, occasional rupturing of blood vessels and erythrocytes, cellular infiltration and hyperplasia (Igeh \& Avenant-Oldewage, 2020). 
Parasitic infections by monogeneans are common in farmed and wild fish populations of various environments. However, infections are worse with inadequate water quality. Therefore, the present study corroborates the potential damages caused by monogeneans in gills of host fish. Disease management is essential for the regional and global growth of aquaculture.

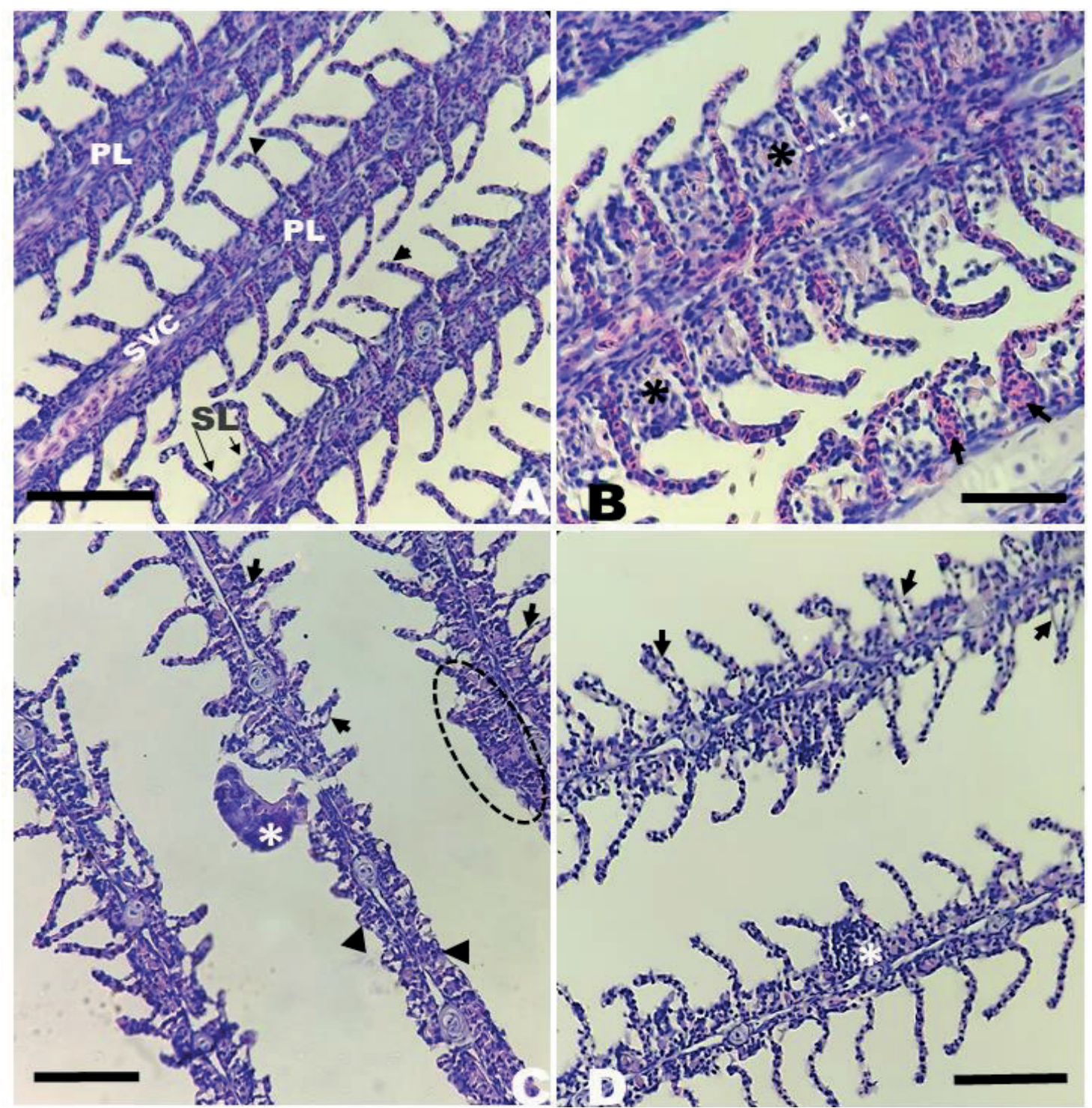

Figure 1. Histological sections of gills of Colossoma macropomum (PROVIDE AUTHOR AND YEAR) parasitized with monogeneans. A. Control branchial tissue highlighting the main structures: primary lamella (LP), secondary lamella (LS), central venous sinus (SVC) and pillar cells (arrowhead). B. Branchial tissue showing hyperplasia (asterisks) with fusion of the secondary lamellae (F) and congestion (arrow). C. Branchial filament with a fixed monogenean (asterisk), where the branchial epithelium detachment (arrows), shortening of the secondary lamellae (arrowheads) and area with total fusion of the secondary lamellae (dashed) are observed. D. Areas with displacement of gill epithelium (arrows) and focal hyperplasia of epithelial cells (asterisk). Scale bar $=30 \mu \mathrm{m}$. 


\section{Acknowledgements}

The authors gratefully acknowledge the Conselho Nacional de Desenvolvimento Científico e Tecnológico (CNPq, Brazil), for the productivity research grant awarded to...... (Grant No 303013/2015-0)

\section{References}

Aragort, V., Morales, G., León, E., Pino, L. A., Guillén, A., \& Silva, M. (2002). Patologías asociadas a monogeneos branquiales en cachama bajo cultivo. Veterinaria Tropical, 27(2), 75-85.

Boeger, W. A., \& Viana, R. T. (2006). Monogenoidea. In V. E. Thatcher (Ed.), Amazon fish parasites (pp. 42-116). Sofia, Moscow: Pensoft Publishers.

Braga, M. P., Araújo, S. B. L., \& Boeger, W. A. (2014). Patterns of interaction between Neotropical freshwater fishes and their gill Monogenoidea (Platyhelminthes). Parasitology Research, 113(2), 481-490. doi: 10.1007/s00436-013-3677-8

Bush, A. O., Lafferty, K. D., Lotz, J. M., \& Shostak, A. W. (1997). Parasitology meets ecology on its own terms: Margolis et al. Revisited. Journal of Parasitology, 83(4), 575-583. doi: $10.2307 / 3284227$

Campos, C. M., Moraes, J. R. E., \& Moraes, F. R. (2011). Histopathology of gills of Piaractus mesopotamicus (Holmberg, 1887) and Prochilodus lineatus (Valenciennes, 1836) infested by monogenean and myxosporea, caugth in Aquidauana River, State of Mato Grosso do Sul, Brazil. Revista Brasileira de Parasitologia Veterinária, 20(1), 67-70. doi: 10.1590/S1984-29612011000100014
Eiras, J. C., Takemoto, R. M., \& Pavanelli, G. C. (2006). Métodos de estudo e técnicas laboratoriais em parasitologia de peixes (2a ed. rev. Ampl.). Maringá: Eduem.

Evans, D. H., Piermarini, P. M., \& Choe, K. P. (2005). The multifunctional fish gill: dominant site of gas exchange, osmoregulation, acid-base regulation, and excretion of nitrogenous waste. Physiological Review, 85(1), 97-177. doi: 10.1152/physrev.00050.2003

Grano-Maldonado, M. I., Rodríguez-Santiago, M. A., García-Vargas, F., Nieves-Soto, M., \& Soares, F. (2018). An emerging infection caused by Gyrodactylus cichlidarum Paperna, 1968 (Monogenea: Gyrodactylidae) associated with massive mortality on farmed tilapia Oreochromis niloticus (L.) on the Mexican Pacific coast. Latin American Journal of Aquatic Research, 46(5), 961-968. doi: 10.3856/vo 146-issue5-fulltext-9

Hoai, T. D. (2020). Reproductive strategies of parasitic flatworms (Platyhelminthes, Monogenea): the impact on parasite management in aquaculture. Aquaculture International, 28, 421-447. doi: 10.1007/ s10499-019-00471-6

Igeh, P. C., \& Avenant-Oldewage, A. (2020). Pathological effects of Cichlidogyrus philander Douëllou, 1993 (Monogenea, Ancyrocephalidae) on the gills of Pseudocrenilabrus philander (Weber, 1897) (Cichlidae). Journal of Fish Diseases, 43(2), 177-184. doi: 10.1111/jfd.13121

Kaur, P., \& Shrivastav, R. (2014). Histological effect of monogenean parasites on gills of freshwater carps. European Journal of Biotechnology and Biosciences, 2(2), 5053. 
Nogueira, J. N., Santos, G. G., \& TavaresDias, M. (2019). High concentration of levamisole in the diet of Colossoma macropomum (Pisces: Serrasalmidae) is effective for controlling monogenean parasites. Brazilian Journal of Veterinary Parasitology, 28(4), 708-712. doi: 10.1590/ S1984-29612019095

Pahor, E., Fo., Klosterhoff, M. C., Marchiori, N. C., \& Pereira, J., Jr., (2017). Moderate pathogenic effect of Ligophorus uruguayense (Monogenoidea, Ancyrocephalidae) in juvenile mullet Mugil liza (Actinopterygii, Mugilidae) from Brazil. Anais da Academia Brasileira de Ciências, 89(4), 2997-3003. doi: 10.1590/0001-3765201720170232
Poleksić, V., \& Mitrović-Tutundžić, V. (1994). Fish gills as a monitor of sublethal and chronic effects of pollution. Sublethal and chronic effects of pollutants on freshwater fish. Oxford: Fishing News Books.

Schwaiger, J., Wanke, R., Adam, S., Pawert, M., Honnen, W., \& Triebskorn, R. (1997). The use of histopathological indicators to evaluate contaminant-related stress in fish. Journal of Aquatic Ecosystem Stress and Recovery 6, 75-86. doi: 10. 1023/A:1008212000208

Whittington, I. D., \& Chisholm, L. A. (2008). Diseases caused by Monogenea. In J. C. Eiras, H. Segner, T. Wahli, \& B. G. Kapoor (Eds.), Fishes diseases (pp. 683-816). New Hampshire: Science Publishers. 
